\title{
Influence of Different Sources of Liming Materials with Soil Test Dose \& Nutrient Expert on Concentration \& Uptake of the Micronutrients and Heavy Metals for Maize Crop Grown in Acid Soil of Odisha, India
}

\author{
Rahul Dev Behera ${ }^{1}$ and S. K. Pattanayak ${ }^{2}$ \\ ${ }^{1}$ Soil Sc. \& Ag. Chem., Krishi Vigyan Kendra, Bolangir, Pin-767002, India \\ ${ }^{2}$ Dept. of Soil Sc. \& Ag. Chemistry, OUAT, Bhubaneswar, Pin-751003, India \\ *Corresponding author
}

Keywords

Stromatolyte,

Calcium silicate,

Paper mill sludge,

Iron, Manganese,

Cupper, Zinc, Lead,

Chromium and

Acid soil

\section{Article Info}

\section{Accepted:}

15 December 2019

Available Online:

20 January 2020

\section{A B S T R A C T}

A field experiment was conducted to study the "Influence of different sources of Liming materials with soil test dose \& nutrient expert on Concentration \& Uptake of the micronutrients \& heavymetals for Maize crop grown in Acid Soil of Odisha" in the village MV-13 in Malkangiri district of Odisha. The soil was ameliorated with three different sources of liming materials (paper mill sludge @ 0.1LR, Stromatolyte@ 0.1 LR and Calcium Silicate @ 0.1 LR) added with soil test dose and nutrient expert. Results indicated that the application of FYM significantly increase the concentration \& uptake of Fe, Mn, $\mathrm{Cu}, \mathrm{Zn}, \mathrm{Pb} \& \mathrm{Cr}$ by the crop compare to the control treatment. The concentration of $\mathrm{Mn}$, $\mathrm{Cu}, \mathrm{Zn} \& \mathrm{~Pb}$ was more in stover than root than grain but the concentration of $\mathrm{Fe} \& \mathrm{Cr}$ was more in root than stover than grain. The maximum concentration of micronutrients follows the order : $\mathrm{Fe}>\mathrm{Cu}>\mathrm{Mn}>\mathrm{Zn}$ and in heavy metals $\mathrm{Cr}$ was greater concentration than $\mathrm{Pb}$. The uptake of $\mathrm{Cu}, \mathrm{Zn}, \mathrm{Pb} \& \mathrm{Cr}$ was more in stover, than grain than root but the uptake of $\mathrm{Fe}$ was more in root than stover than grain and uptake of $\mathrm{Mn}$ was more in stover than root than grain. The maximum uptake of micronutrients follows the order: $\mathrm{Fe}>\mathrm{Cu}>\mathrm{Mn}>\mathrm{Zn}$ and in heavy metals $\mathrm{Pb}$ was greater uptake than $\mathrm{Cr}$. The total uptake of $\mathrm{Fe}, \mathrm{Mn}, \mathrm{Zn} \& \mathrm{~Pb}$ was more in NE+ST+FYM treatment i.e $16,2.6,1.6 \& 0.6 \mathrm{~kg} / \mathrm{ha}$ but in $\mathrm{Cu}$ total uptake was more in STD+ST+FYM i.e $4.1 \mathrm{~kg} / \mathrm{ha}$ and in $\mathrm{Cr}$ was more in NE+CS+FYM i.e. 0.56 $\mathrm{kg} / \mathrm{ha}$. Among the three liming materials the stromatolyte gives the greater efficiency than the calcium silicate than the paper mill sludge and the application of liming materials with NE gives the higher efficiency than the soil test dose.

\section{Introduction}

Under emerging challenges of natural resource-base degradation, declining crop productivity, and ecological problems with the existing rice-wheat system, the maize based cropping systems are emerging as an alternative option for diversification of ricewheat and rice-rice production systems in India (Pooniya et al, 2015). With the development of high yielding varieties and hybrids in maize which are competitive to rice 
with respect to farm-profitability and resource-use-efficiency under diverse climatic conditions; the maize-wheat cropping system is gaining importance as a predominant maize based system (1.8 $\mathrm{m} \mathrm{ha})$ in India alone being 3rd major rotation which contributes $\sim 3 \%$ in national food basket (Jat et al., 2013).

Saharawat et al., (2010) reported that simulated, attainable and actual maize yields in maize growing agro-ecologies in SouthAsia revealed wide management yield gaps ranging from $36-77 \%$. These yield gaps are due to poor yielding genotypes and crop establishment techniques as well as imbalanced nutrient applications as $15-45 \%$ maize area remains unfertilized (Jat et al., 2011). By introduction of single cross hybrids in maize, productivity increased up to $7.0 \mathrm{t} / \mathrm{ha}$ and total nutrient removal has also increased to $420 \mathrm{~kg} / \mathrm{ha}$ (Jat et al., 2013). Adopting best fertilization management practices by following the SSNM-NE concept have shown improvement in yields and it is based on estimations of crop need-based nutrientsupplying capacity as per target yield. International Plant Nutrition Institute (IPNI) in collaboration with CIMMYT has recently developed a Nutrient Expert (NE), a nutrient decision support system, based on SSNM principles. NE provides fertilizer recommendations by considering yield responses and targeted agronomic efficiencies along with contribution of nutrients from indigenous sources. This system follows systematic approach of capturing site-specific information that is important for developing a location-specific-recommendation.

NE has been successfully used to provide fertilizer recommendations in major maize growing agro-ecologies of country and also increased yield and farm profitability over existing fertilizer recommendations. A study showed that the average use of $\mathrm{N}, \mathrm{P} 2 \mathrm{O} 5$, and
$\mathrm{K}_{2} \mathrm{O}$ by farmers is 193,89 , and $114 \mathrm{~kg} / \mathrm{ha}$, but, fertilizer application based on NE reduces $\mathrm{N}, \mathrm{P}_{2} \mathrm{O}_{5}$ and $\mathrm{K}_{2} \mathrm{O}$ use by $32,50,66 \mathrm{~kg} / \mathrm{ha}$ and indicating 17,56 , and $58 \%$ reductions in fertilizer use over farmers' practice (Satyanarayana et al., 2013, Jat et al., 2013). It also helps in providing information about prevailing climatic conditions affecting nutrient management under specific-location and right rate of nutrients to meet attainable yield goals. Considering above facts, an attempt has been made in this study to develop SSNM-NE practice besides reorienting nutrient management practices for enhancing productivity and farmprofitability.

\section{Materials and Methods}

Three different types of liming materials were used in the experiment. These were Paper Mill Sludge (PMS), Stromatolyte (ST) and Calcium Silicate (CS). Liming materials were applied mixed with FYM in the field. Absolute control treatment was included without any addition of external source of nutrients. The test crop Maize received 12 treatments. Each treatment was replicated three times and imposed over statistically laid out field with Radomised Block Design (RBD) in the field.

The different plant parts like leaf, shoot, cob, grain and roots were collected and kept in separate envelops, washed, labeled properly and dried in hot air oven till a constant weight was recorded. Each sample was grinded separately and was used for analysis of micronutrients and heavymetals. The samples were digested in diacid mixture $\left[\mathrm{HNO}_{3}\right.$ : $\mathrm{HClO}_{4}$ (3:2)]. The reading was taken in Atomic Absorption Spectrophotometer (AAS). Before the analysis of micronutrients and heavymetals the liming materials were analysed and characterised as follows. 


\section{Results and Discussion}

Concentration and Uptake of the iron (Fe) as influenced by the different sources of liming materials

The concentration and uptake of $\mathrm{Fe}$ in different maize plants like grain, stover and root has been presented in the Table-3. The concentration of the ' $\mathrm{Fe}$ ' was more in maize root (ranging from 0.167 to $0.438 \%$ ) than through stover (ranging from 0.020 to 0.047 $\%$ ) than through grain (ranging from 0.012 to $0.049 \%$ ). So also the uptake of 'Fe' was more in maize root (ranging from 0.52 to 7.03 $\mathrm{kg} / \mathrm{ha}$ ) than through stover (ranging from 0.094 to $5.69 \mathrm{~kg} / \mathrm{ha}$ ) than through grain (ranging from 0.24 to $3.19 \mathrm{~kg} / \mathrm{ha}$ ). The total uptake under different treatments varied between 2 to $16 \mathrm{~kg} / \mathrm{ha}$, lowest with control and highest with NE+ST+FYM.

The application of FYM significantly increase the concentration and uptake of ' $\mathrm{Fe}$ ' by the crop compare to the control treatment. The application of STD and NE significantly increase the concentration and uptake of ' $\mathrm{Fe}$ ' by the crop but the combine application of STD and NE with FYM increases the concentration and uptake of 'Fe' more compare to the STD and NE alone, indicating the importance of importance of organic integration in improving the efficiency. The application of liming materials with NE and FYM gives the higher concentration and uptake of 'Fe' by the crop compare to the application of liming materials with STD and FYM except uptake in stover (NE+CS+FYM) and root $(\mathrm{NE}+\mathrm{PMS}+\mathrm{FYM})$. Among the three liming materials the application of stromatolyte (ST) with NE and FYM has greater efficiency to increase the ' $\mathrm{Fe}$ ' concentration in grain $(0.049 \%)$, stover $(0.047 \%)$, root $(0.380 \%)$ and ' $\mathrm{Fe}$ ' uptake in grain $(3.19 \mathrm{~kg} / \mathrm{ha})$, stover $(5.69 \mathrm{~kg} / \mathrm{ha})$, root $(7.03 \mathrm{~kg} / \mathrm{ha})$ compare to the others respectively (Table-3). The application of liming materials with STD follows the order : ST $>$ CS $>$ PMS and the application of liming materials with NE follows the order : $\mathrm{ST}>\mathrm{CS}>\mathrm{PMS}$.

Concentration and Uptake of the Manganese (Mn) as influenced by the different sources of liming materials

The concentration and uptake of $\mathrm{Mn}$ in different maize plants like grain, stover and root has been presented in the Table-4. The concentration of the 'Mn' was more in maize stover (ranging from 0.007 to $0.018 \%$ ) than through root (ranging from 0.004 to $0.016 \%$ ) than through grain (ranging from 0.0007 to $0.0025 \%$ ). So also the uptake of 'Fe' was more in maize stover (ranging from 0.33 to $2.18 \mathrm{~kg} / \mathrm{ha}$ ) than through root (ranging from 0.01 to $0.30 \mathrm{~kg} / \mathrm{ha}$ ) than through grain (ranging from 0.01 to $0.16 \mathrm{~kg} / \mathrm{ha}$ ). The total uptake under different treatments varied between 0.4 to $2.6 \mathrm{~kg} / \mathrm{ha}$, lowest with control and highest with NE+ST+FYM.

The application of FYM significantly increase the concentration and uptake of ' $\mathrm{Mn}$ ' by the crop compare to the control treatment. The application of STD and NE significantly increase the concentration and uptake of ' $\mathrm{Mn}$ ' by the crop but the combine application of STD and NE with FYM increases the concentration and uptake of 'Mn' more compare to the STD and NE alone, indicating the importance of importance of organic integration in improving the efficiency. The application of liming materials with NE and FYM gives the higher concentration and uptake of ' $\mathrm{Fe}$ ' by the crop compare to the application of liming materials with STD and FYM except uptake in stover (NE+CS+FYM) and root (NE+PMS+FYM). Among the three liming materials the application of stromatolyte (ST) with NE and FYM has greater efficiency to increase the ' $\mathrm{Fe}$ ' 
concentration in grain $(0.0025 \%)$, stover $(0.018 \%)$, root $(0.016 \%)$ and 'Fe' uptake in grain $(0.16 \mathrm{~kg} / \mathrm{ha})$, stover $(2.18 \mathrm{~kg} / \mathrm{ha})$, root $(0.30 \mathrm{~kg} / \mathrm{ha})$ compare to the others respectively (Table-4). The application of liming materials with STD follows the order: ST $>$ CS $>$ PMS and the application of liming materials with NE follows the order: $\mathrm{ST}>\mathrm{CS}>\mathrm{PMS}$.

\section{Concentration and Uptake of the Cupper (Cu) as influenced by the different sources of liming materials}

The concentration and uptake of ' $\mathrm{Cu}$ ' in different maize plants like grain, stover and root has been presented in the Table-5. The concentration of the ' $\mathrm{Cu}$ ' was more in maize stover (ranging from 0.001 to $0.030 \%$ ) than through root (ranging from 0.0023 to 0.0076 $\%$ ) than through grain (ranging from 0.0005 to $0.0029 \%$ ). But the uptake of ' $\mathrm{Fe}$ ' was more in maize stover (ranging from 0.05 to $3.81 \mathrm{~kg} / \mathrm{ha}$ ) than through grain (ranging from 0.01 to $0.19 \mathrm{~kg} / \mathrm{ha}$ ) than through root (ranging from 0.01 to $0.14 \mathrm{~kg} / \mathrm{ha}$ ). The total uptake under different treatments varied between 0.1 to $4.1 \mathrm{~kg} / \mathrm{ha}$, lowest with control and highest with STD+ST+FYM.

The application of FYM significantly increase the concentration and uptake of ' $\mathrm{Cu}$ ' by the crop compare to the control treatment. The application of STD and NE significantly increase the concentration and uptake of ' $\mathrm{Cu}$ ' by the crop but the combine application of STD and NE with FYM increases the concentration and uptake of ' $\mathrm{Cu}$ ' more compare to the STD and NE alone, indicating the importance of importance of organic integration in improving the efficiency. The application of liming materials with $\mathrm{NE}$ and FYM gives the higher concentration and uptake of ' $\mathrm{Cu}$ ' by the crop compare to the application of liming materials with STD and FYM except uptake in stover (NE+ST+FYM) and root (NE+PMS+FYM). Among the three liming materials the application of stromatolyte (ST) with NE and FYM has greater efficiency to increase the ' $\mathrm{Cu}$ ' concentration in grain $(0.0029 \%)$, stover $(0.030 \%)$, root $(0.0076 \%)$ and 'Cu' uptake in grain $(0.19 \mathrm{~kg} / \mathrm{ha})$, root $(0.14 \mathrm{~kg} / \mathrm{ha})$ except stover compare to the others respectively (Table-5). The application of liming materials with STD follows the order: ST>CS $>$ PMS and the application of liming materials with NE follows the order : $S T>C S>P M S$.

Concentration and Uptake of the Zinc (Zn) as influenced by the different sources of liming materials

The concentration and uptake of ' $\mathrm{Zn}$ ' in different maize plants like grain, stover and root has been presented in the Table-6. The concentration of the ' $\mathrm{Zn}$ ' was more in maize stover (ranging from 0.0012 to $0.0099 \%$ ) than through root (ranging from 0.0020 to $0.0063 \%$ ) than through grain (ranging from 0.0011 to $0.0046 \%$ ). But the uptake of ' $\mathrm{Zn}$ ' was more in maize stover (ranging from 0.06 to $1.20 \mathrm{~kg} / \mathrm{ha}$ ) than through grain (ranging from 0.02 to $0.30 \mathrm{~kg} / \mathrm{ha}$ ) than through root (ranging from 0.01 to $0.12 \mathrm{~kg} / \mathrm{ha}$ ). The total uptake under different treatments varied between 0.1 to $1.6 \mathrm{~kg} / \mathrm{ha}$, lowest with control and highest with NE+ST+FYM.

The application of FYM significantly increase the concentration and uptake of ' $\mathrm{Zn}$ ' by the crop compare to the control treatment. The application of STD and NE significantly increase the concentration and uptake of ' $\mathrm{Zn}$ ' by the crop but the combine application of STD and NE with FYM increases the concentration and uptake of ' $\mathrm{Zn}$ ' more compare to the STD and NE alone, indicating the importance of importance of organic integration in improving the efficiency. The application of liming materials with $\mathrm{NE}$ and FYM gives the higher concentration and 
uptake of ' $\mathrm{Zn}$ ' by the crop compare to the application of liming materials with STD and FYM except uptake in stover (NE+CS+FYM) and root $(\mathrm{NE}+\mathrm{PMS}+\mathrm{FYM})$. Among the three liming materials the application of stromatolyte (ST) with NE and FYM has greater efficiency to increase the ' $\mathrm{Zn}$ ' concentration in grain $(0.0046 \%)$, stover $(0.0099 \%)$, root $(0.0063 \%)$ and 'Zn' uptake in grain $(0.30 \mathrm{~kg} / \mathrm{ha})$, stover $(1.20 \mathrm{~kg} / \mathrm{ha})$ and root $(0.12 \mathrm{~kg} / \mathrm{ha})$ compare to the others respectively (Table-6). The application of liming materials with STD follows the order : ST $>$ CS $>$ PMS and the application of liming materials with NE follows the order : $\mathrm{ST}>\mathrm{CS}>\mathrm{PMS}$.

Concentration and Uptake of the Lead $(\mathrm{Pb})$ as influenced by the different sources of liming materials

The concentration and uptake of ' $\mathrm{Pb}$ ' in different maize plants like grain, stover and root has been presented in the Table-7. The concentration of the ' $\mathrm{Pb}$ ' was more in maize stover (ranging from 0.0028 to $0.0043 \%$ ) than through root (ranging from 0.0009 to $0.0044 \%$ ) than through grain (ranging from 0.0004 to $0.0028 \%$ ). But the uptake of ' $\mathrm{Pb}$ ' was more in maize stover (ranging from 0.13 to $0.40 \mathrm{~kg} / \mathrm{ha}$ ) than through grain (ranging from 0.01 to $0.16 \mathrm{~kg} / \mathrm{ha}$ ) than through root (ranging from 0.01 to $0.04 \mathrm{~kg} / \mathrm{ha}$ ). The total uptake under different treatments varied between 0.2 to $0.6 \mathrm{~kg} / \mathrm{ha}$, lowest with control and highest with $\mathrm{NE}+\mathrm{ST}+\mathrm{FYM}$.

The application of FYM significantly increase the concentration and uptake of ' $\mathrm{Pb}$ ' by the crop compare to the control treatment. The application of STD and NE significantly increase the concentration and uptake of ' $\mathrm{Pb}$ ' by the crop but the combine application of STD and NE with FYM decreases the concentration in grain, stover and uptake in grain compare to the STD and NE alone. The application of PMS and CS with STD and FYM gives the higher concentration and uptake of ' $\mathrm{Pb}$ ' by the crop compare to the application with NE and FYM but the application of ST with NE and FYM gives the higher concentration and uptake of ' $\mathrm{Pb}$ ' by the crop compare to the application with STD and FYM. Among the three liming materials the application of stromatolyte (ST) with NE and FYM has greater efficiency to increase the ' $\mathrm{Pb}$ ' concentration in grain $(0.0027 \%)$, stover $(0.0028 \%)$, root $(0.0039 \%)$ and ' $\mathrm{Pb}$ ' uptake in grain $(0.16 \mathrm{~kg} / \mathrm{ha})$ and root $(0.04$ $\mathrm{kg} / \mathrm{ha}$ ) except stover compare to the others respectively (Table-7). The application of liming materials with STD follows the order : PMS $>$ ST $>C S$ and the application of liming materials with NE follows the order : ST $>$ PMS $>$ CS.

Concentration and Uptake of the Chromium (Cr) as influenced by the different sources of liming materials

The concentration and uptake of ' $\mathrm{Cr}$ ' in different maize plants like grain, stover and root has been presented in the Table-8. The concentration of the ' $\mathrm{Cr}$ ' was more in maize root (ranging from 0.0031 to $0.0058 \%$ ) than through grain (ranging from 0.0008 to 0.0032 $\%$ ) than through stover (ranging from 0.0007 to $0.0024 \%$ ). But the uptake of ' $\mathrm{Cr}$ ' was more in maize stover (ranging from 0.03 to $0.29 \mathrm{~kg} / \mathrm{ha}$ ) than through grain (ranging from 0.02 to $0.21 \mathrm{~kg} / \mathrm{ha}$ ) than through root (ranging from 0.01 to $0.07 \mathrm{~kg} / \mathrm{ha}$ ). The total uptake under different treatments varied between 0.06 to $0.56 \mathrm{~kg} / \mathrm{ha}$, lowest with control and highest with NE+CS+FYM.

The application of FYM significantly increase the concentration and uptake of ' $\mathrm{Cr}$ ' by the crop compare to the control treatment. The application of STD and NE significantly increase the concentration and uptake of ' $\mathrm{Cr}$ ' by the crop but the combine application of 
STD and NE with FYM decreases the concentration and uptake of ' $\mathrm{Cr}$ ' more compare to the STD and NE alone. The application of liming materials with NE and FYM gives the higher concentration and uptake of ' $\mathrm{Zn}$ ' by the crop compare to the application of liming materials with STD and FYM except uptake in root (NE+PMS+FYM). Among the three liming materials the application of CS with NE and
FYM has greater efficiency to increase the ' $\mathrm{Cr}$ ' concentration in grain $(0.0032 \%)$, stover $(0.0024 \%)$, root $(0.0035 \%)$ and ' $\mathrm{Cr}$ ' uptake in grain $(0.21 \mathrm{~kg} / \mathrm{ha})$, stover $(0.29 \mathrm{~kg} / \mathrm{ha})$ and root $(0.06 \mathrm{~kg} / \mathrm{ha})$ compare to the others respectively (Table-8). The application of liming materials with STD follows the order : CS $>$ PMS $>S T$ and the application of liming materials with NE follows the order : $\mathrm{CS}>\mathrm{PMS}>\mathrm{ST}$.

Table.1 Characterisation of liming materials

\begin{tabular}{|c|c|c|c|}
\hline Parameters (mg/kg) & Calcium Silicate & $\begin{array}{c}\text { Paper Mill } \\
\text { Sludge }\end{array}$ & Stromatolyte \\
\hline Iron (Fe) & 259 & 252 & 275 \\
\hline Manganese (Mn) & 38 & 17 & 41 \\
\hline Cupper $(\mathbf{C u})$ & 4.3 & 1.5 & 8.5 \\
\hline Zinc $(\mathbf{Z n})$ & 10.1 & 9.9 & 10.8 \\
\hline Chromium $(\mathbf{C r})$ & 290 & 16.3 & 10.3 \\
\hline Lead $(\mathbf{P b})$ & 9.2 & 12.1 & 13.2 \\
\hline
\end{tabular}

Table. 2 Treatment details

\begin{tabular}{|c|c|}
\hline SL. No. & Treatments \\
\hline $\mathbf{1}$ & Absolute Control \\
\hline $\mathbf{2}$ & Farm Yard Manure (FYM) \\
\hline $\mathbf{3}$ & Soil Test Based Dose (STD) \\
\hline $\mathbf{4}$ & Nutrient Expert (NE) \\
\hline $\mathbf{5}$ & Soil Test Based Dose STD + FYM \\
\hline $\mathbf{6}$ & Nutrient Expert NE + FYM \\
\hline $\mathbf{7}$ & STD + Paper Mill Sludge (PMS) + FYM \\
\hline $\mathbf{8}$ & NE + Paper Mill Sludge (PMS) + FYM \\
\hline $\mathbf{9}$ & STD + Calcium Silicate (CS) + FYM \\
\hline $\mathbf{1 0}$ & NE + Calcium Silicate (CS) + FYM \\
\hline $\mathbf{1 1}$ & STD + Stromatolyte (ST) + FYM \\
\hline $\mathbf{1 2}$ & NE + Stromatolyte (ST) + FYM \\
\hline
\end{tabular}


Table.3 Concentration and uptake of the iron $(\mathrm{Fe})$ as influenced by the different sources of liming materials

\begin{tabular}{|c|c|c|c|c|c|c|c|}
\hline Treatments & \multicolumn{3}{|c|}{ Concentration (\%) } & \multicolumn{3}{c|}{ Uptake (Kg/ha) } & \\
\hline & Grain & Stover & Root & Grain & Stover & Root & Total \\
\hline Absolute Control & 0.012 & 0.020 & 0.167 & 0.24 & 0.94 & 0.52 & 2 \\
\hline FYM & 0.013 & 0.023 & 0.191 & 0.31 & 1.59 & 0.90 & 3 \\
\hline STD & 0.014 & 0.025 & 0.241 & 0.65 & 2.35 & 1.64 & 5 \\
\hline Nutrient Expert & 0.018 & 0.026 & 0.268 & 0.86 & 2.16 & 2.52 & 6 \\
\hline STD + FYM & 0.017 & 0.026 & 0.310 & 0.91 & 3.04 & 2.67 & 7 \\
\hline NE + FYM & 0.018 & 0.027 & 0.327 & 1.00 & 2.97 & 3.24 & 7 \\
\hline STD + PMS + FYM & 0.020 & 0.027 & 0.353 & 1.16 & 3.24 & 4.59 & 9 \\
\hline NE + PMS + FYM & 0.027 & 0.027 & 0.438 & 1.63 & 3.43 & 4.56 & 10 \\
\hline STD + CS + FYM & 0.022 & 0.028 & 0.310 & 1.42 & 4.09 & 4.46 & 10 \\
\hline NE + CS + FYM & 0.033 & 0.032 & 0.352 & 2.16 & 3.81 & 5.84 & 12 \\
\hline STD + ST + FYM & 0.036 & 0.038 & 0.377 & 2.29 & 5.17 & 6.52 & 14 \\
\hline NE + ST + FYM & 0.049 & 0.047 & 0.380 & 3.19 & 5.69 & 7.03 & 16 \\
\hline CD(0.05) & $\mathbf{0 . 0 3}$ & $\mathbf{0 . 0 6}$ & $\mathbf{0 . 0 4}$ & $\mathbf{0 . 0 9}$ & $\mathbf{1 . 4 4}$ & $\mathbf{0 . 0 8}$ & \\
\hline CV(\%) & $\mathbf{4 . 6 7}$ & $\mathbf{3 . 1 9}$ & $\mathbf{6 . 2 3}$ & $\mathbf{3 . 8 8}$ & $\mathbf{2 7 . 4 6}$ & $\mathbf{1 0 . 4 3}$ & \\
\hline
\end{tabular}

Table.4 Concentration and uptake of the Manganese (Mn) as influenced by the different sources of liming materials

\begin{tabular}{|c|c|c|c|c|c|c|c|}
\hline Treatments & \multicolumn{3}{|c|}{ Concentration (\%) } & \multicolumn{3}{c|}{ Uptake (Kg/ha) } & \\
\hline & Grain & Stover & Root & Grain & Stover & Root & Total \\
\hline Absolute Control & 0.0007 & 0.007 & 0.004 & 0.01 & 0.33 & 0.01 & 0.4 \\
\hline FYM & 0.0008 & 0.008 & 0.005 & 0.02 & 0.55 & 0.02 & 0.6 \\
\hline STD & 0.0010 & 0.009 & 0.006 & 0.05 & 0.85 & 0.04 & 0.9 \\
\hline Nutrient Expert & 0.0011 & 0.010 & 0.007 & 0.05 & 0.83 & 0.07 & 1.0 \\
\hline STD + FYM & 0.0015 & 0.008 & 0.007 & 0.08 & 0.94 & 0.06 & 1.1 \\
\hline NE + FYM & 0.0019 & 0.012 & 0.009 & 0.11 & 1.32 & 0.09 & 1.5 \\
\hline STD + PMS + FYM & 0.0017 & 0.011 & 0.010 & 0.10 & 1.32 & 0.13 & 1.6 \\
\hline NE + PMS + FYM & 0.0020 & 0.014 & 0.011 & 0.12 & 1.78 & 0.11 & 2.0 \\
\hline STD + CS + FYM & 0.0019 & 0.013 & 0.011 & 0.12 & 1.90 & 0.16 & 2.2 \\
\hline NE + CS + FYM & 0.0021 & 0.015 & 0.012 & 0.14 & 1.79 & 0.20 & 2.1 \\
\hline STD + ST + FYM & 0.0024 & 0.016 & 0.015 & 0.15 & 2.18 & 0.26 & 2.6 \\
\hline NE + ST + FYM & 0.0025 & 0.018 & 0.016 & 0.16 & 2.18 & 0.30 & 2.6 \\
\hline CD(0.05) & $\mathbf{0 . 0 4}$ & $\mathbf{0 . 0 7}$ & $\mathbf{0 . 0 3}$ & $\mathbf{0 . 0 1}$ & $\mathbf{0 . 1 7}$ & $\mathbf{0 . 0 5}$ & \\
\hline CV(\%) & $\mathbf{4 . 2 3}$ & $\mathbf{5 . 6 5}$ & $\mathbf{3 . 7 6}$ & $\mathbf{4 . 3 5}$ & $\mathbf{7 . 3 9}$ & $\mathbf{5 . 5 1}$ & \\
\hline
\end{tabular}


Table.5 Concentration and uptake of the Cupper $(\mathrm{Cu})$ as influenced by the different sources of liming materials

\begin{tabular}{|c|c|c|c|c|c|c|c|}
\hline Treatments & \multicolumn{3}{|c|}{ Concentration (\%) } & \multicolumn{3}{c|}{ Uptake (Kg/ha) } & \\
\hline & Grain & Stover & Root & Grain & Stover & Root & Total \\
\hline Absolute Control & 0.0005 & 0.001 & 0.0023 & 0.01 & 0.05 & 0.01 & 0.1 \\
\hline FYM & 0.0006 & 0.002 & 0.0033 & 0.01 & 0.14 & 0.02 & 0.2 \\
\hline STD & 0.0007 & 0.002 & 0.0039 & 0.03 & 0.19 & 0.03 & 0.3 \\
\hline Nutrient Expert & 0.0008 & 0.003 & 0.0044 & 0.04 & 0.25 & 0.04 & 0.3 \\
\hline STD + FYM & 0.0009 & 0.005 & 0.0045 & 0.05 & 0.59 & 0.04 & 0.7 \\
\hline NE + FYM & 0.0010 & 0.006 & 0.0053 & 0.06 & 0.66 & 0.05 & 0.8 \\
\hline STD + PMS + & 0.0011 & 0.008 & 0.0057 & 0.06 & 0.96 & 0.07 & 1.1 \\
\hline FYM & & & & & & & \\
\hline NE + PMS + FYM & 0.0015 & 0.010 & 0.0060 & 0.09 & 1.27 & 0.06 & 1.4 \\
\hline STD + CS + FYM & 0.0018 & 0.015 & 0.0066 & 0.12 & 2.19 & 0.10 & 2.4 \\
\hline NE + CS + FYM & 0.0020 & 0.022 & 0.0069 & 0.13 & 2.62 & 0.11 & 2.9 \\
\hline STD + ST + FYM & 0.0021 & 0.028 & 0.0070 & 0.13 & 3.81 & 0.12 & 4.1 \\
\hline NE + ST + FYM & 0.0029 & 0.030 & 0.0076 & 0.19 & 3.63 & 0.14 & 4.0 \\
\hline CD(0.05) & $\mathbf{0 . 0 3}$ & $\mathbf{0 . 0 6}$ & $\mathbf{0 . 0 9}$ & $\mathbf{0 . 0 0}$ & $\mathbf{0 . 2 5}$ & $\mathbf{0 . 0 3}$ & \\
\hline CV(\%) & $\mathbf{4 . 7 6}$ & $\mathbf{3 . 2 1}$ & $\mathbf{6 . . 5 8}$ & $\mathbf{3 . 5 4}$ & $\mathbf{1 0 . 7 5}$ & $\mathbf{6 . 4 5}$ & \\
\hline
\end{tabular}

Table.6 Concentration and uptake of the Zinc $(\mathrm{Zn})$ as influenced by the different sources of liming materials

\begin{tabular}{|c|c|c|c|c|c|c|c|}
\hline Treatments & \multicolumn{3}{|c|}{ Concentration (\%) } & \multicolumn{3}{c|}{ Uptake (Kg/ha) } & \\
\hline & Grain & Stover & Root & Grain & Stover & Root & Total \\
\hline Absolute Control & 0.0011 & 0.0012 & 0.0020 & 0.02 & 0.06 & 0.01 & 0.1 \\
\hline FYM & 0.0018 & 0.0015 & 0.0022 & 0.04 & 0.10 & 0.01 & 0.2 \\
\hline STD & 0.0019 & 0.0036 & 0.0026 & 0.09 & 0.34 & 0.02 & 0.5 \\
\hline Nutrient Expert & 0.0022 & 0.0040 & 0.0029 & 0.10 & 0.33 & 0.03 & 0.5 \\
\hline STD + FYM & 0.0024 & 0.0042 & 0.0031 & 0.13 & 0.49 & 0.03 & 0.7 \\
\hline NE + FYM & 0.0025 & 0.0044 & 0.0034 & 0.14 & 0.48 & 0.03 & 0.7 \\
\hline STD + PMS + FYM & 0.0026 & 0.0047 & 0.0044 & 0.15 & 0.56 & 0.06 & 0.8 \\
\hline NE + PMS + FYM & 0.0029 & 0.0048 & 0.0044 & 0.18 & 0.61 & 0.05 & 0.8 \\
\hline STD + CS + FYM & 0.0034 & 0.0051 & 0.0048 & 0.22 & 0.74 & 0.07 & 1.0 \\
\hline NE + CS + FYM & 0.0038 & 0.0054 & 0.0059 & 0.25 & 0.64 & 0.10 & 1.0 \\
\hline STD + ST + FYM & 0.0041 & 0.0079 & 0.0060 & 0.26 & 1.07 & 0.10 & 1.4 \\
\hline NE + ST + FYM & 0.0046 & 0.0099 & 0.0063 & 0.30 & 1.20 & 0.12 & 1.6 \\
\hline CD(0.05) & $\mathbf{0 . 0 2}$ & $\mathbf{0 . 0 4}$ & $\mathbf{0 . 0 3}$ & $\mathbf{0 . 0 1}$ & $\mathbf{0 . 0 8}$ & $\mathbf{0 . 0 7}$ & \\
\hline CV(\%) & $\mathbf{3 . 4 3}$ & $\mathbf{4 . 5 3}$ & $\mathbf{5 . 3 2}$ & $\mathbf{4 . 0 8}$ & $\mathbf{8 . 5 8}$ & $\mathbf{7 . 3 2}$ & \\
\hline
\end{tabular}


Table.7 Concentration and uptake of the Lead $(\mathrm{Pb})$ as influenced by the different sources of liming materials

\begin{tabular}{|c|c|c|c|c|c|c|c|}
\hline Treatments & \multicolumn{3}{|c|}{ Concentration (\%) } & \multicolumn{3}{c|}{ Uptake (Kg/ha) } & \\
\hline & Grain & Stover & Root & Grain & Stover & Root & Total \\
\hline Absolute Control & 0.0004 & 0.0028 & 0.0022 & 0.01 & 0.13 & 0.01 & 0.2 \\
\hline FYM & 0.0010 & 0.0029 & 0.0023 & 0.02 & 0.30 & 0.01 & 0.3 \\
\hline STD & 0.0021 & 0.0038 & 0.0019 & 0.10 & 0.36 & 0.01 & 0.5 \\
\hline Nutrient Expert & 0.0028 & 0.0043 & 0.0021 & 0.13 & 0.36 & 0.02 & 0.5 \\
\hline STD + FYM & 0.0016 & 0.0034 & 0.0028 & 0.09 & 0.40 & 0.02 & 0.5 \\
\hline NE + FYM & 0.0023 & 0.0036 & 0.0044 & 0.13 & 0.40 & 0.04 & 0.6 \\
\hline STD + PMS + FYM & 0.0014 & 0.0028 & 0.0016 & 0.09 & 0.38 & 0.03 & 0.5 \\
\hline NE + PMS + FYM & 0.0008 & 0.0022 & 0.0010 & 0.05 & 0.27 & 0.02 & 0.3 \\
\hline STD + CS + FYM & 0.0012 & 0.0024 & 0.0010 & 0.08 & 0.35 & 0.01 & 0.4 \\
\hline NE + CS + FYM & 0.0005 & 0.0020 & 0.0009 & 0.03 & 0.24 & 0.01 & 0.3 \\
\hline STD + ST + FYM & 0.0015 & 0.0026 & 0.0014 & 0.09 & 0.31 & 0.02 & 0.4 \\
\hline NE + ST + FYM & 0.0027 & 0.0028 & 0.0039 & 0.16 & 0.36 & 0.04 & 0.6 \\
\hline CD(0.05) & $\mathbf{0 . 0 3}$ & $\mathbf{0 . 0 4}$ & $\mathbf{0 . 0 5}$ & $\mathbf{0 . 0 1}$ & $\mathbf{0 . 0 4}$ & $\mathbf{0 . 0 2}$ & \\
\hline CV(\%) & $\mathbf{4 . 1 2}$ & $\mathbf{3 . 2 4}$ & $\mathbf{4 . 3 5}$ & $\mathbf{6 . 7 9}$ & $\mathbf{7 . 5 8}$ & $\mathbf{5 . 4 3}$ & \\
\hline
\end{tabular}

Table.8 Concentration and uptake of the Chromium $(\mathrm{Cr})$ as influenced by the different sources of liming materials

\begin{tabular}{|c|c|c|c|c|c|c|c|}
\hline Treatments & \multicolumn{3}{|c|}{ Concentration (\%) } & \multicolumn{3}{c|}{ Uptake (Kg/ha) } & \\
\hline & Grain & Stover & Root & Grain & Stover & Root & Total \\
\hline Absolute Control & 0.0008 & 0.0007 & 0.0036 & 0.02 & 0.03 & 0.01 & 0.06 \\
\hline FYM & 0.0010 & 0.0009 & 0.0039 & 0.02 & 0.06 & 0.02 & 0.10 \\
\hline STD & 0.0011 & 0.0007 & 0.0040 & 0.05 & 0.07 & 0.03 & 0.15 \\
\hline Nutrient Expert & 0.0015 & 0.0010 & 0.0042 & 0.07 & 0.08 & 0.04 & 0.19 \\
\hline STD + FYM & 0.0025 & 0.0015 & 0.0044 & 0.13 & 0.18 & 0.04 & 0.35 \\
\hline NE + FYM & 0.0010 & 0.0008 & 0.0039 & 0.06 & 0.09 & 0.04 & 0.19 \\
\hline STD + PMS + FYM & 0.0015 & 0.0005 & 0.0050 & 0.09 & 0.06 & 0.07 & 0.22 \\
\hline NE + PMS + FYM & 0.0025 & 0.0010 & 0.0058 & 0.15 & 0.13 & 0.06 & 0.34 \\
\hline STD + CS + FYM & 0.0024 & 0.0014 & 0.0031 & 0.15 & 0.19 & 0.05 & 0.39 \\
\hline NE + CS + FYM & 0.0032 & 0.0024 & 0.0035 & 0.21 & 0.29 & 0.06 & 0.56 \\
\hline STD + ST + FYM & 0.0014 & 0.0012 & 0.0034 & 0.09 & 0.18 & 0.05 & 0.32 \\
\hline NE + ST + FYM & 0.0016 & 0.0015 & 0.0035 & 0.10 & 0.18 & 0.06 & 0.34 \\
\hline CD(0.05) & $\mathbf{0 . 0 4}$ & $\mathbf{0 . 0 2}$ & $\mathbf{0 . 0 3}$ & $\mathbf{0 . 0 1}$ & $\mathbf{0 . 0 2}$ & $\mathbf{0 . 0 1}$ & \\
\hline CV(\%) & $\mathbf{3 . 6 7}$ & $\mathbf{5 . 4 1}$ & $\mathbf{4 . 2 4}$ & $\mathbf{4 . 9 8}$ & $\mathbf{8 . 4 2}$ & $\mathbf{6 . 2 3}$ & \\
\hline
\end{tabular}


In conclusion, results indicated that the application of FYM significantly increase the concentration and uptake of $\mathrm{Fe}, \mathrm{Mn}, \mathrm{Cu}, \mathrm{Zn}$, $\mathrm{Pb}$ and $\mathrm{Cr}$ by the crop compare to the control treatment. The concentration of $\mathrm{Mn}, \mathrm{Cu}, \mathrm{Zn}$ and $\mathrm{Pb}$ was more in stover than root than grain but the concentration of $\mathrm{Fe}$ and $\mathrm{Cr}$ was more in root than stover than grain. The maximum concentration of micronutrients follows the order: $\mathrm{Fe}>\mathrm{Cu}>\mathrm{Mn}>\mathrm{Zn}$ and in heavy metals $\mathrm{Cr}$ was greater concentration than $\mathrm{Pb}$. The uptake of $\mathrm{Cu}, \mathrm{Zn}, \mathrm{Pb}$ and $\mathrm{Cr}$ was more in stover, than grain than root but the uptake of $\mathrm{Fe}$ was more in root than stover than grain and uptake of Mn was more in stover than root than grain. The maximum uptake of micronutrients follows the order: $\mathrm{Fe}>\mathrm{Cu}>\mathrm{Mn}>\mathrm{Zn}$ and in heavy metals $\mathrm{Pb}$ was greater uptake than $\mathrm{Cr}$. The total uptake of Fe, $\mathrm{Mn}, \mathrm{Zn}$ and $\mathrm{Pb}$ was more in $\mathrm{NE}+\mathrm{ST}+\mathrm{FYM}$ treatment i.e. 16, 2.6, 1.6 and $0.6 \mathrm{~kg} / \mathrm{ha}$ but in $\mathrm{Cu}$ total uptake was more in STD+ST+FYM i.e. $4.1 \mathrm{~kg} / \mathrm{ha}$ and in $\mathrm{Cr}$ was more in $\mathrm{NE}+\mathrm{CS}+\mathrm{FYM}$ i.e $0.56 \mathrm{~kg} / \mathrm{ha}$. Among the three liming materials the stromatolyte gives the greater efficiency than the calcium silicate than the paper mill sludge and the application of liming materials with NE gives the higher efficiency than the soil test dose.

\section{References}

Jat M L, Saharawa Y S, Majumdar K and Gupta R. 2011. Addressing climate change effects and meeting maize demand for Asia. (In) 11th Asian Maize Conference, Nanning, China, 7-
11 Nov, pp 370-2.

Jat M L, Satyanarayana T, Majumdar K, Parihar C M, Jat S L, Majumdar K, Satyanarayana T, Pampolino M, Dutta S, Jat M L, Sulewski G and Johnston A M. 2013. Nutrient Expert for hybrid maize (version 1.1). A decision support tool for providing field specific fertilizer recommendations for tropical hybrid maize. International Plant Nutrition Institute, Gurgaon, India.

Pooniya, V., Jat, S L., Choudhury, A. K., Singh, A. K., Parihar, C. M., Bana, R. S., Swarnalakshmi, K. and Rana, K. S., (2015). Nutrient Expert assisted site-specific-nutrient-management: An alternative precision fertilization technology for maize-wheat cropping system in South-Asian Indo-Gangetic Plains. Indian Journal of Agricultural Sciences. 85 (8): 996-1002.

Saharawat Y S, Singh B, Malik R K, Ladha J K, Gathala M K, Jat M L and Kumar V. 2010. Evaluation of alternative tillage and crop establishment methods in a rice-wheat rotation in NW IGP. Field Crop Research, 116: 260-7.

Satyanarayana T, Majumdar K, Pampolino M, Johnston A M and Jat M L. 2013. Nutrient Expert TM: A tool to optimize nutrient use and improve productivity of maize. Better CropsSouth Asia, 97: 21-4.

\section{How to cite this article:}

Rahul Dev Behera and Pattanayak, S. K. 2020. Influence of Different Sources of Liming Materials with Soil Test Dose and Nutrient Expert on Concentration and Uptake of the Micronutrients and Heavy Metals for Maize Crop Grown in Acid Soil of Odisha, India. Int.J.Curr.Microbiol.App.Sci. 9(01): 2147-2156. doi: https://doi.org/10.20546/ijcmas.2020.901.245 